\title{
A NOVEL SHOE COMFORTABILITY EVALUATION METHOD TO REFLECT RECOGNITION IN NURSING OF DIABETIC FOOT AMONG DIABETES PATIENTS IN SOUTHWEST CHINA
}

\author{
Mingyu HU ${ }^{1}$, Xueling TAN ${ }^{1}$, Quting HUANG ${ }^{1}$, Yaoxia $\mathrm{LIU}^{3}$, Bo XU ${ }^{1}$, Jin ZHOU ${ }^{1,2 *}$ \\ ${ }^{1}$ National Engineering Laboratory for Clean Technology of Leather Manufacture, Sichuan University; Chengdu 610065, P. R.
} China

${ }^{2}$ Science Lab, Zhejiang red dragonfly footwear Co., LTD., Zhejiang Province, Wenzhou 325100, P. R. China

${ }^{3}$ West China School of clinical medicine, Sichuan University; Chengdu 610065, P. R. China

Received: 26.11.2018

Accepted: 17.05 .2019

https://doi.org/10.24264/Ifj.19.2.1

\begin{abstract}
A NOVEL SHOE COMFORTABILITY EVALUATION METHOD TO REFLECT RECOGNITION IN NURSING OF DIABETIC FOOT AMONG DIABETES PATIENTS IN SOUTHWEST CHINA

ABSTRACT. Effective footwear and offloading interventions were recommended in the official guidance for diabetic foot (DF) management, where unfortunately the detail of shoes' definition was still unclear; meanwhile, in China, 0.1 billion population has been diagnosed with diabetes mellitus, but what kind of shoes worn by Chinese diabetic patients was unknown. Therefore, the aim of this study was to establish a system to quantify the comfortability of shoes among DF patients, and based on this method conduct a random survey of shoe wearing situation in diabetes population in Sichuan province. 472 participants joined in this study and their shoes were defined as structure of shoes, upper materials, status of welt, heel height and thickness of sole. Each part of shoes was first quantified into scores; and then aggregated scores were calculated as the final assessment result for the shoes. Three levels reflecting the recognition of shoes from patients were classified into: discomfort; moderate comfort; comfort. Finally, a univariate analysis with least significant difference (LSD) was exerted in shoe wearing comfort for variables of age, gender, BMI, occupation, history of diabetes mellitus and Michigan score. Results show that numbers of elder and male patients wear comfort shoes were more than that of female and younger ones; meanwhile, those findings were recorded to be significant. Overall, comfortability quantification system was established and both gender and age factors determined the consciousness and knowledge in shoe wearing; thereby, our system was valid and shoes wearing education for female and younger diabetic patients are urgent. KEY WORDS: diabetic foot, diabetic shoes, comfortability evaluation, foot nursing, ulceration
\end{abstract}

\section{O NOUĂ METODĂ PENTRU EVALUAREA CONFORTULUI ÎNCĂLȚĂMINTEI CARE SĂ FIE RECUNOSCUTĂ ÎN ASISTENȚA PACIENȚILOR CU DIABET DIN SUD-VESTUL CHINEI}

REZUMAT. În ghidul oficial pentru îngrijirea piciorului diabetic se recomandă încălțăminte eficientă și intervenții de reducere a presiunii, însă, din păcate, definiția detaliată a încălțămintei este încă neclară; între timp, în China, 0,1 miliarde de persoane au fost diagnosticate cu diabet zaharat, dar nu se cunoaște ce fel de încălțăminte poartă pacienții diabetici chinezi. Prin urmare, scopul acestui studiu a fost de a stabili un sistem de cuantificare a confortului încălțămintei în rândul pacienților cu diabet și, pe baza acestei metode, să se efectueze un sondaj aleator privind încălțămintea purtată de populația de diabet din provincia Sichuan. În acest studiu s-au alăturat 472 de participanți, iar încălțămintea acestora a fost definită în funcție de structură, materialele pentru fețe, starea ramei, înălțimea tocului și grosimea tălpii. Fiecare parte a pantofilor a fost mai întâi cuantificată în scoruri; iar scorurile agregate au fost calculate ca rezultat final al evaluării încălțămintei. S-au stabilit trei niveluri care reflectă nivelul de confort al încălțămintei pacienților: disconfort; confort moderat; confort. În cele din urmă, s-a efectuat o analiză univariată cu testul celei mai puțin semnificative diferențe (LSD) privind confortul încălțămintei pentru variabilele de vârstă, sex, IMC, ocupație, istoricul diabetului zaharat și scorul Michigan. Rezultatele arată că numărul de pacienți vârstnici și bărbați care poartă încălț̆minte confortabilă a fost mai mare decât cel al pacienților mai tineri și de sex feminin; aceste constatări au fost înregistrate ca fiind semnificative. În ansamblu, a fost stabilit sistemul de cuantificare a confortului, iar factorii de gen și de vârstă au determinat nivelul de sensibilizare și de cunoaștere privind purtarea încălțămintei; prin urmare, sistemul nostru este valid, iar educația privind purtarea pantofilor comozi în cazul pacienților cu diabet zaharat de sex feminin și mai tineri este imperioasă.

CUVINTE CHEIE: picior diabetic, pantofi pentru diabetici, evaluarea confortului, asistență medicală la nivelul piciorului, ulcerație

\section{UNE NOUVELLE MÉTHODE D’ÉVALUATION DU CONFORT DE CHAUSSURES RECONNUE DANS LES SOINS DES PATIENTS DIABÉTIQUES DU} SUD-OUEST DE LA CHINE

RÉSUMÉ. Dans le guide officiel sur les soins des pieds pour diabétiques, des chaussures et des interventions efficaces sur le soulagement de la pression sont recommandées, mais malheureusement, la définition détaillée des chaussures n'est toujours pas claire ; en Chine, 0,1 milliard de personnes ont été diagnostiquées avec le diabète, mais on ne connait pas quel type de chaussures portent les diabétiques chinois. L'objectif de cette étude était donc d'établir un système permettant de quantifier le confort des chaussures chez les patients diabétiques, et à partir de cette méthode, de mener une enquête aléatoire sur la situation des chaussures portées par la population diabétique de la province du Sichuan. 472 personnes ont participé à cette étude et leurs chaussures ont été définies comme suit: structure des chaussures, matériaux de la tige, statut de la trépointe, hauteur du talon et épaisseur de la semelle. Chaque partie de chaussures a d'abord été quantifiée en scores; et ensuite, les scores agrégés ont été calculés comme résultat final de l'évaluation des chaussures. Trois niveaux reflétant la reconnaissance des chaussures par les patients ont été classés en: inconfort; confort modéré; confort. Enfin, une analyse univariée avec le test de différence significative minimale (LSD) a été réalisée en ce qui concerne le confort des chaussures pour des variables d'âge, de sexe, d'IMC, de profession, d'histoire du diabète sucré et de score de Michigan. Les résultats montrent que le nombre de patients âgés et d'hommes portant des chaussures de confort était supérieur à celui des femmes et des patients plus jeunes ; ces résultats ont été jugés significatifs. Dans l'ensemble, le système de quantification du confort a été mis en place et des facteurs liés au sexe et à l'âge ont déterminé le degré de sensibilisation et de connaissance en ce qui concerne les chaussures; par conséquent, notre système est valable et une éducation sur les chaussures confortables pour les femmes et les patients diabétiques jeunes est impérative.

MOTS CLÉS : pied diabétique, chaussures pour les diabétiques, évaluation du confort, les soins du pied, ulcération

\footnotetext{
"Correspondence to: Assoc. Prof. Ph.D. Jin ZHOU, National Engineering Laboratory for Clean Technology of Leather Manufacture, Sichuan University; Chengdu 610065, P. R. China; Fax:008613880467494, Tel:13880467494, E-mail: zj_scu@scu.edu.cn
} 


\section{INTRODUCTION}

Loss of tactile sensation, deformities, ulceration and even the amputation in the foot are usually observed in diabetes patients. Those symptoms are the clinical manifestation of diabetes foot (DF) [1] and they have significantly increased the risk of morbidity and mortality for patients. Critical point in DF daily care is the ulcer prevention, where abnormal high plantar pressure, excessive loads on metatarsal heads or toes, and cracks of skin are main management targets $[2,3]$. Currently, around $2 \%$ yearly incidence rate of ulceration was reported in diabetes group but recurrence rates was between $30 \%-40 \%$ during the first twelve months after rehabilitation [4-8]. Since, occurrences and reoccurrences of ulcers increase both the economical and physical burden of patients, efficient nursing and management for ulcer prevention were required among diabetes patients, [9] which was also important to reduce amputations [10].

Among the approaches of DF management, the pressure relieving is the priority. Varied pressure reliving methods have been reported in literatures. Usually, shoes or socks were prevalent. Waaijman et al. [11] used custommade footwear in off-loading of foot pressure to avoid ulceration; preventive foot care socks were also beneficial in increasing the contact area of foot to decrease the plantar foot pressure [12]. Unexpectedly, a low cost of running shoes was also reported as a very minimally acceptable choice for patients without deformities [13]. While nursing of ulcers, felted foam applied in toe ulcers and wound healing, flexor tenotomies in healing ulcers were also effective and safe approaches [14, 15]. Further, L. Uccioli et al. designed special manufactured shoes to prevent relapses of ulceration in DF [2]. Officially, the international working group on the diabetes foot (IWGDF) has published a guidance on the clinical nursing and management for diabetes foot. This guidance indicated that effective footwear and offloading interventions shall be recommended to diabetes patients [11]. However, in this guidance, the detail of shoes' definition was failed to achieve. Unfortunately, in majority Asia countries, including China, DF intensive care following the IWGDF's guidance is still a tough mission, as lacking professional podiatric services and welltrained foot-care medical centers [12]. Moreover, although more than 0.1 billion population has been confirmed as diabetes mellitus in China; how the current situation of those patients in wearing shoes in China is also a blank zone. It was insisted that correct shoes wearing are the first-step to the ulcer prevention. Purpose of this study was to establish a comfortability quantification system to quantify the comfortability of shoes among DF patients, and then conduct a random survey on the shoe wearing in diabetes population in Sichuan province to know the general situation of daily shoe wearing of Chinese diabetes. According to the literature, hypothesis: 1. a criterion to quantify the shoes comfortability could be established; 2 . shoe wearing situation was only related to the social experience, where elder people care more about their shoes in daily life.

\section{EXPERIMENTAL}

\section{Material and Method}

\section{Subjects}

In this study, totally 472 participants from outpatient service of West China Hospital of Sichuan university in Chengdu during 20152017 were randomly recruited. The criteria of inclusion were: (1) patients were diagnosed with diabetes mellitus; (2) no amputee or ulcers in the foot or history; (3) wearing the daily usualused shoes. Parameters such as age, gender, height, weight, BMI, history of diabetes mellitus, occupation (Heavy (frontline worker at heavy industry), Moderate (general manual workers), Light (civilian and design workers) and Other 
relaxed work (freelance and unemployed)), shoe information were recorded. Following the principle of Helsinki Declaration, the whole process of test was introduced to participants and their formal approvals were authorized.

\section{Quantify Assessment for Shoes}

Five key factors of shoes were measured: structure of shoes $(S s)$, upper materials $(U m)$, status of welt (Ws), heel height and thickness of sole, where a clean height of shoes $(C h)$ was calculated by heel height minus thickness of sole. Referring the guidance of IWGDF, in which thin bottom, soft, breathable, loose and delicate structure and materials were recommended [13]. Moreover, in this study, a quantification system was established to quantify each factor of shoe by a certain score (Table 1) and the aggregated suitable score (S) represents the final assessment result. It can be explained by the following formula (Eq 1). Range of $S$ valued from -8 points to 7 points. The whole assessment was completed by an experienced footwear engineer.

$S s+U m-C h-W s=S$

Table 1: Quantification system for each factor of shoes

\begin{tabular}{|c|c|c|}
\hline Parameter & Point & Category \\
\hline \multirow{5}{*}{ Structure (Ss) } & 1 & Single shoes \\
\hline & 2 & Cloth shoes \\
\hline & 3 & Sandal shoes \\
\hline & 4 & Leather shoes \\
\hline & 5 & Sports shoes \\
\hline \multirow{4}{*}{ Upper materials (Um) } & 1 & Others \\
\hline & 2 & Artificial leather \\
\hline & 3 & Textile \\
\hline & 4 & Leather \\
\hline \multirow{6}{*}{ Clean heel height (Ch) } & 1 & $0 \mathrm{~mm}$ to $10 \mathrm{~mm}$ \\
\hline & 2 & $11 \mathrm{~mm}$ to $20 \mathrm{~mm}$ \\
\hline & 3 & $21 \mathrm{~mm}$ to $30 \mathrm{~mm}$ \\
\hline & 4 & $31 \mathrm{~mm}$ to $40 \mathrm{~mm}$ \\
\hline & 5 & $41 \mathrm{~mm}$ to $50 \mathrm{~mm}$ \\
\hline & 6 & Above $51 \mathrm{~mm}$ \\
\hline \multirow{2}{*}{ Welt (Ws) } & 1 & Open status \\
\hline & 2 & Close status \\
\hline
\end{tabular}

Diabetes Foot Inspection

Michigan NeuropathyScreeningInstrument (MNSI) which contains fifteen questions was first filled in by patients themselves; appearance and deformities of foot, dryness, infection and cleft of skin, as well as ulcers were then checked by the physician [16]. Ankle reflex, toe vibration sensation and tactile sensation were tested by reflex hammer, $128 \mathrm{~Hz}$ tuning fork and 10-gram filament, respectively [17]. At last, overall scores were calculated and this score indicated the DF severity, where, previous study reported that score 4 was a threshold for DF risk alert [18].

\section{Data Processing and Statistical Analysis}

Shoe's quantification scores (S) were classified into three levels: discomfort (-8 to 0 ); moderate comfort (1 to 4); comfort (5 to 7). Discomfort (G1), moderate comfort (G2) and comfort (G3) indicated the recognition from the patient to the shoe. The higher comfort scores implied that the patient has a high recognition on the effect of shoes on the ulcer prevention and vice versa. Participants also divided into three age groups, as youth group (A1; aged 1 to 39 ), middle-aged group (A2; aged 40 to 59), old group (A3; aged above 60 ).

In the process of statistical analyses, one-sample K-S test was first exerted to all parameters and all parameters followed the normal distribution; then descriptive analysis was applied to all the quantized indexes. At last, a univariate analysis with Least-Significant Difference (LSD) was exerted to explore the differences in shoe wearing comfort for variables of age, gender, BMI, occupation, history of diabetes mellitus and Michigan score. Statistical analysis was operated under software SPSS (V22, IBM, USA), with significant level of 0.05 and confidence interval of $95 \%$.

\section{RESULTS}

Demographic information showed that the gender ratio is 205:267 (Male: Female), mean 
age is 59.7 (SD:11.0), mean $\mathrm{BMI}$ is 24.2 (3.6), mean MNSI score was 5.4 (2.7), mean history of diabetes mellitus were 7.00 (6.35) years, occupation distribution result was in table 2 . Further, 9 subjects were diagnosed with type 1 diabetes and others were type 2 diabetes.

Table 2: Number and ratio of each classification

\begin{tabular}{|c|c|c|c|c|c|c|c|c|}
\hline Gender & Suitable & Numbers & $\begin{array}{l}\text { Ratio in } \\
\text { total (\%) }\end{array}$ & $\begin{array}{c}\text { Ratio in } \\
\text { gender (\%) }\end{array}$ & Occupation & Numbers & $\begin{array}{l}\text { Ratio in } \\
\text { total (\%) }\end{array}$ & $\begin{array}{l}\text { Ratio in } \\
\text { gender } \\
(\%)\end{array}$ \\
\hline \multirow{9}{*}{ Female } & \multirow{4}{*}{ G1 } & \multirow{4}{*}{32} & \multirow{4}{*}{6.78} & \multirow{4}{*}{11.99} & Heavy & 2 & 0.42 & 0.75 \\
\hline & & & & & Moderate & 8 & 1.69 & 3.00 \\
\hline & & & & & Light & 8 & 1.69 & 3.00 \\
\hline & & & & & Others & 14 & 2.97 & 5.24 \\
\hline & \multirow{5}{*}{$\mathrm{G} 2$} & \multirow{4}{*}{162} & \multirow{4}{*}{34.32} & \multirow{4}{*}{60.67} & Heavy & 23 & 4.87 & 8.61 \\
\hline & & & & & Moderate & 53 & 11.23 & 19.85 \\
\hline & & & & & Light & 45 & 9.53 & 16.85 \\
\hline & & & & & Others & 41 & 8.69 & 15.36 \\
\hline & & \multirow{4}{*}{73} & \multirow{4}{*}{15.47} & \multirow{4}{*}{27.34} & Heavy & 12 & 2.54 & 4.49 \\
\hline \multirow{15}{*}{ Male } & \multirow{3}{*}{ G3 } & & & & Moderate & 23 & 4.87 & 8.61 \\
\hline & & & & & Light & 18 & 3.81 & 6.74 \\
\hline & & & & & Others & 20 & 4.24 & 7.49 \\
\hline & \multirow{4}{*}{ G1 } & \multirow{4}{*}{11} & \multirow{4}{*}{2.33} & \multirow{4}{*}{5.37} & Heavy & 1 & 0.21 & 0.49 \\
\hline & & & & & Moderate & 5 & 1.06 & 2.44 \\
\hline & & & & & Light & 4 & 0.85 & 1.95 \\
\hline & & & & & Others & 1 & 0.21 & 0.49 \\
\hline & \multirow{4}{*}{ G2 } & \multirow{4}{*}{121} & \multirow{4}{*}{25.64} & \multirow{4}{*}{59.02} & Heavy & 17 & 3.60 & 8.29 \\
\hline & & & & & Moderate & 29 & 6.14 & 14.15 \\
\hline & & & & & Light & 45 & 9.53 & 21.95 \\
\hline & & & & & Others & 30 & 6.36 & 14.63 \\
\hline & \multirow{4}{*}{ G3 } & \multirow{4}{*}{73} & \multirow{4}{*}{15.47} & \multirow{4}{*}{35.61} & Heavy & 5 & 1.06 & 2.44 \\
\hline & & & & & Moderate & 18 & 3.81 & 8.78 \\
\hline & & & & & Light & 33 & 6.99 & 16.10 \\
\hline & & & & & Others & 17 & 3.60 & 8.29 \\
\hline
\end{tabular}

In terms of shoes wearing, totally 43 diabetes patients $(9.11 \%)$ wear G1-kind shoes, in which the number of males was 11 (ratio in total: $2.33 \%$ ) and that of females was $32(6.78 \%)$; particularly, 1 man (0.21\%) and 2 women (0.42\%) participants engaged on heavy work; 5 men $(1.06 \%)$ and 8 women (1.69\%) were working on moderate physical jobs. 238 participants $(59.60 \%)$ wear G2-kind shoes, where male participants were 121 (25.64\%) and female ones were 162 (34.32\%). Meanwhile, 146 participants (30.94\%) wear G3-kind shoes during their daily life and men's wearing numbers were the same to their female counterparts. (see Table 2).

Table 3: Number and ratio of each classification

\begin{tabular}{|c|c|c|c|c|c|c|c|c|c|}
\hline Age & Numbers & Suitable & Numbers & $\begin{array}{c}\text { Ratio } \\
\text { in total } \\
(\%)\end{array}$ & $\begin{array}{c}\text { Ratio in } \\
\text { each age } \\
\text { group } \\
(\%)\end{array}$ & Occupation & Numbers & $\begin{array}{c}\text { Ratio } \\
\text { in total } \\
(\%)\end{array}$ & $\begin{array}{c}\text { Ratio in } \\
\text { each age } \\
\text { group } \\
(\%)\end{array}$ \\
\hline \multirow{12}{*}{$\mathrm{A} 1$} & \multirow{12}{*}{24} & \multirow{4}{*}{ G1 } & \multirow{4}{*}{5} & \multirow{4}{*}{1.06} & \multirow{4}{*}{20.83} & Heavy & 0 & 0.00 & 0.00 \\
\hline & & & & & & Moderate & 2 & 0.42 & 8.33 \\
\hline & & & & & & Light & 2 & 0.42 & 8.33 \\
\hline & & & & & & Others & 1 & 0.21 & 4.17 \\
\hline & & \multirow{4}{*}{ G2 } & \multirow{4}{*}{13} & \multirow{4}{*}{2.75} & \multirow{4}{*}{54.17} & Heavy & 0 & 0.00 & 0.00 \\
\hline & & & & & & Moderate & 4 & 0.85 & 16.67 \\
\hline & & & & & & Light & 3 & 0.64 & 12.50 \\
\hline & & & & & & Others & 6 & 1.27 & 25.00 \\
\hline & & \multirow{4}{*}{ G3 } & \multirow{4}{*}{6} & \multirow{4}{*}{1.27} & \multirow{4}{*}{25.00} & Heavy & 0 & 0.00 & 0.00 \\
\hline & & & & & & Moderate & 1 & 0.21 & 4.17 \\
\hline & & & & & & Light & 4 & 0.85 & 16.67 \\
\hline & & & & & & Others & 1 & 0.21 & 4.17 \\
\hline
\end{tabular}




\begin{tabular}{|c|c|c|c|c|c|c|c|c|c|}
\hline \multirow{11}{*}{$\mathrm{A} 2$} & \multirow{11}{*}{181} & \multirow{4}{*}{ G1 } & \multirow{4}{*}{23} & \multirow{4}{*}{4.87} & \multirow{4}{*}{12.71} & Heavy & \multirow{3}{*}{$\begin{array}{l}2 \\
6 \\
4\end{array}$} & \multirow{2}{*}{$\begin{array}{l}0.42 \\
1.27\end{array}$} & \multirow{2}{*}{$\begin{array}{l}1.10 \\
3.31\end{array}$} \\
\hline & & & & & & Moderate & & & \\
\hline & & & & & & Light & & 0.85 & 2.21 \\
\hline & & & & & & Others & 11 & 2.33 & 6.08 \\
\hline & & & & & & Heavy & 18 & 3.81 & 9.94 \\
\hline & & & & & & Moderate & 34 & 7.20 & 18.78 \\
\hline & & G2 & 112 & 23.73 & 61.88 & Light & 31 & 6.57 & 17.13 \\
\hline & & & & & & Others & 29 & 6.14 & 16.02 \\
\hline & & & & & & Heavy & 7 & 1.48 & 3.87 \\
\hline & & & & & & Moderate & 16 & 3.39 & 8.84 \\
\hline & & G3 & 46 & 9.15 & 25.41 & Light & 12 & 2.54 & 6.63 \\
\hline & & & & & & Others & 11 & 2.33 & 6.08 \\
\hline & & & & & & Heavy & 1 & 0.21 & 0.37 \\
\hline & & G1 & 15 & & 562 & Moderate & 5 & 1.06 & 1.87 \\
\hline & & 01 & 13 & 3.18 & 0.02 & Light & 6 & 1.27 & 2.25 \\
\hline & & & & & & Others & 3 & 0.64 & 1.12 \\
\hline & & & & & & Heavy & 22 & 4.66 & 8.24 \\
\hline & & & & & & Moderate & 44 & 9.32 & 16.48 \\
\hline A3 & $26 /$ & $\mathrm{GL}$ & 158 & $33.4 /$ & 59.18 & Light & 56 & 11.86 & 20.97 \\
\hline & & & & & & Others & 36 & 7.63 & 13.48 \\
\hline & & & & & & Heavy & 10 & 2.12 & 3.75 \\
\hline & & & & & & Moderate & 24 & 5.08 & 8.99 \\
\hline & & G3 & 94 & 19.92 & 35.21 & Light & 35 & 7.42 & 13.11 \\
\hline & & & & & & Others & 25 & 5.30 & 9.36 \\
\hline
\end{tabular}

Patients in three age groups (Table 3) were 24 people (5.08\%) from $A 1,181$ people (38.34\%) from $A 2$ and 267 people (56.57\%) from A3. With the age increasing, the number of wearing G1-kind shoes decreased, while the number of $\mathrm{G} 2$ and $\mathrm{G} 3$ increased. Ratio of wearing for G1, G2 and G3 kind shoes in A1 group was G1:G2:G3=20.83\%: 54.17\%: $25.00 \%$ (ratio in all age group $=1.06 \%: 2.75 \%: 1.27 \%)$, and in $\mathrm{A} 2$ group was $\mathrm{G1}: \mathrm{G} 2: \mathrm{G} 3=12.71 \%$ : $61.88 \%$ : $25.41 \%$ (ratio in all age group $=4.87 \%: 23.73 \%: 9.75 \%$ ), and in A3 group was G1:G2:G3=5.62\%: 59.18\%: $35.21 \%$ (ratio in all age group $=3.18 \%$ : $33.47 \%$ : $19.92 \%)$.

Univariate analysis results showed that model of age, genderand their mix have significant influence on the suitable score (age factor: $p=0.001<0.05$, gender factor: $p=0.000<0.05$; age*gender factor: $p=0.024<0.05)$. LSD result indicated that $\mathrm{G} 1$ to $\mathrm{G} 2$ was 0.498 , and $\mathrm{G} 1$ V.S. G3: $p=0.040<0.05, G 2$ V.S. G3: $p=0.003<0.05$. No significances were founded in variables of occupation, BMI, history of diabetes mellitus and Michigan score.

\section{DISCUSSION}

In terms of demographic findings, average BMI of diabetes patients were reported as 25.0 in China [19]; while that of this study was 24.2 (3.6), which is very close to the guidelines. Those two close results improved that participants recruited in this study were generalizable enough. Although, Golmohammadi [20] indicated that occupational stress is an important factor induce to the diabetes mellitus, factors such as occupation were not found significant in selection of shoe wearing.

In this study, a quantification system was established to quantify the comfort of shoes. According to each part of shoe structure, criterion of rating for their level of suitability for diabetic patients was following literature stated by IWGDF. Then the sum of scores were calculated and the result implied a general comfort level of particular shoes, or a kind of consciousness on the suitability of shoes. For instance, discomfort illustrated that no attention or no correct knowledge in wearing shoes; moderate comfort explained that although patients paid attention to the shoe's suitability, they were lacking knowledge of what a pair of 
suitable shoes should be; comfort indicated that both two aspects were applied in wearing shoes. Unfortunately, there were no similar studies in current database. Nevertheless, our first hypothesis is proved to be available.

In comprehending our findings, only $30.94 \%$ of patients wear suitable shoes during their daily life, which suggested that the diabetes patients in China have a low consciousness on shoes in terms of foot protection, in contrast with their Europe counterparts [5]. Two-ways ANOVA assessed the joint-effects of gender and age, and significant findings were obtained. In terms of age factor, with the social experience increasing, patients are gradually aware the importance of foot nursing and they know how to wear suitable shoes for foot protection. Meanwhile, significant differences between discomfort-moderate comfort and discomfort-comfort groups were also observed. Hence, those clues proved that shoes wearing education to the younger diabetes patients were necessary. In terms of gender, female patients wearing discomfort shoes were doubled than that of male group and the gender variation was significant. This revealed that women are easy to omit the important of shoes wearing. The high-heeled shoes which are harmful for their gait and posture though, this kind of shoes have prevalent centuries. Our finding was accordance with literature [21]. So, our second hypothesis was manifested to be real.

\section{LIMITATIONS}

Although significant outcomes illustrated general status of shoes wearing in Chinese diabetes patients, Limitations existed and should be declared: (1) The time of this report lasted in three years, some particular shoe stylish such as sheepskin boots etc., was not included in this survey; (2) Since our study was the first to quantify the shoe, so no previous studies on shoes can be referred, but our idea might inspired more people to focus on the comfortability evaluation work.

\section{FUTURE RESEARCH AND IMPLICATIONS}

Our comfortability quantification system accomplished quantified the comfortability of shoes and this was used to disclosed that factors of age and gender have a strong influence on the consciousness and knowledge in shoes wearing of diabetes patients, where male and elder ages showed a better consciousness and knowledge of shoe wearing. So, the consciousness and knowledge education of shoes wearing for female and younger diabetes patients are urgent. And our idea of quantifying comfortability of shoes might inspire more research to focus on the comfortability evaluation work.

\section{CONCLUSION}

Qualification system was useful when quantifying the comfortability of shoes among DF patients; male and older populations paid more attention to their shoes.

\section{Conflict of Interest}

All authors declare that they have no conflict of interest.

\section{Acknowledgements}

The authors appreciate all the participants in this study. Funding: This work was supported by the National Natural Science Foundation of China (grant numbers 31700813); Science and Technology in Sichuan province (grant number 18GJHZ0117). 


\section{REFERENCES}

1. van Netten, J.J., Price, P.E., Lavery, L.A., Monteiro-Soares, M., Rasmussen, A., Jubiz, Y., Bus, S.A., Diabetes Metab Res Rev, 2016, 32, 84-98, https://doi.org/10.1002/dmrr.2701.

2. Uccioli, L., Faglia, E., Monticone, G., Favales, F., Durola, L., Aldeghi, A., Quarantiello, A., Calia, P., Menzinger, G., Diabetes Care, 1995, 18, 1376-1378, https://doi.org/10.2337/ diacare.18.10.1376.

3. Stokes, I.A., Faris, I.B., Hutton, W.C., Acta Orthop Scand, 1975, 46, 839-847, https://doi. org/10.3109/17453677508989271.

4. Prompers, L., Huijberts, M., Apelqvist, J., Jude, E., Piaggesi, A., Bakker, K., Edmonds, M., Holstein, P., Jirkovska, A., Mauricio, D., Ragnarson Tennvall, G., Reike, H., Spraul, M., Uccioli, L., Urbancic, V., Van Acker, K., van Baal, J., van Merode, F., Schaper, N., Diabetologia, 2007, 50, 18-25, https://doi.org/10.1007/ s00125-006-0491-1.

5. Bus, S.A., Armstrong, D.G., van Deursen, R.W., Lewis, J.E., Caravaggi, C.F., Cavanagh, P.R., Diabetes Metab Res Rev, 2016, 32, 25-36, https://doi.org/10.1002/dmrr.2697.

6. Boulton, A.J.M., Kirsner, R.S., Vileikyte, L., $N$ Engl J Med, 2004, 351, 1694-1695, https:// doi.org/10.1056/NEJM200410143511626.

7. Abbott, C.A., Carrington, A.L., Ashe, H., Bath, S., Every, L.C., Griffiths, J., Hann, A.W., Hussein, A., Jackson, N., Johnson, K.E., Ryder, C.H., Torkington, R., Van Ross, E.R.E., Whalley, A.M., Widdows, P., Williamson, S., Boulton, A.J.M., Diabetic Med, 2002, 19, 377-384, https://doi. org/10.1046/j.1464-5491.2002.00698.x.

8. Pound, N., Chipchase, S., Treece, K., Game, F., Jeffcoate, W., Diabetic Med, 2005, 22, 1306-1309, https://doi.org/10.1111/j.14645491.2005.01640.x.
9. Boulton, A.J., Vileikyte, L., RagnarsonTennvall, G., Apelqvist, J., Lancet, 2005, 366, 1719-1724, https://doi.org/10.1016/S01406736(05)67698-2.

10. Ragnarson-Tennvall, G., Apelqvist, J., Diabetologia, 2001, 44, 2077-2087, https:// doi.org/10.1007/s001250100013.

11. Waaijman, R., Keukenkamp, R., Haart, M.D., de Haart, M., Polomski, W.P., Nollet, F., Bus, S.A., Diabetes Care, 2013, 36, 1613, https:// doi.org/10.2337/dc12-1330.

12. Garrow, A.P., van Schie, C.H., Boulton, A.J., Diabetes Care, 2005, 28, 2001-2006, https:// doi.org/10.2337/diacare.28.8.2001.

13. Perry, J.E., Ulbrecht, J.S., Derr, J.A., Cavanagh, P.R., J Bone Joint Surg Am, 1995, 77, 18191828, https://doi.org/10.2106/00004623199512000-00005.

14. van Netten, J.J., Bril, A., van Baal, J.G., J Foot Ankle Res, 2013, 6, 3, https://doi. org/10.1186/1757-1146-6-3.

15. Zimny, S., Schatz, H.U., Diabetic Med, 2003, 20, 622-625, https://doi.org/10.1046/j.14645491.2003.01011.x.

16. Lunetta, M., Le Moli, R., Grasso, G., Sangiorgio, L., Diabetes Res Clin Pract, 1998, 39, 165-172, https://doi.org/10.1016/S01688227(98)00005-9.

17. Malik, R.A., Kallinikos, P., Abbott, C.A., van Schie, C.H.M., Morgan, P., Efron, N., Boulton, A.J.M., Diabetologia, 2003, 46, 683-688, https://doi.org/10.1007/s00125-003-1086-8.

18. Liu, Y.X., Chen, S., Zhou, J. et al., Chinese Journal of Diabetes, 2016, 24, 536-539.

19. Chinese Diabetes Society, Peking University Medical Publisher, 2014. 
20. Golmohammadi, R., Abdulrahman, B., Journal of Medical Sciences, 2006, 6, 2, 241-244, https://doi.org/10.3923/ims.2006.241.244.

21. Shalev, V., Chodick, G., Heymann, A.D., Kokia, E., Public Health, 2005, 119, 45-49, https://doi.org/10.1016/j.puhe.2004.03.004.
(C) 2019 by the author(s). Published by INCDTPICPI, Bucharest, RO. This is an open access article distributed under the terms and conditions of the Creative Commons Attribution license (http:// creativecommons.org/licenses/by/4.0/). 